Ann. Biol. anim. Bioch. Biophys., 1979, 19 (3 A), 695-701.

\title{
Acrosome labelling in mammalian spermatozoa
}

\author{
par V. KOPEČNÝ
}

\begin{abstract}
Institute of Animal Physiology and Genetics, Czechoslovak Academy of Sciences,

CS 27721 Libechov, Czechoslovakia.
\end{abstract}

\begin{abstract}
Summary. Acrosomes of rabbit spermatozoa were intensively labelled 24 to 25 days after an intratesticular injection of $\mathrm{L}-\left(1-{ }^{3} \mathrm{H}\right)$ fucose. The label, representing probably acrosomal glycoprotein, was extracted by procedures known to cause progressive loss of acrosomal enzymes and membranes. Cold $\mathrm{MgCl}_{2}$ solution extracted $46 \mathrm{p.} 100$ of the label ; further treatment with $C T A B$ (cetyltrimethylammonium bromide) reduced the radioactivity to background level. Acrosomal labelling was also prominent in mouse spermatozoa 22 days after an intraperitoneal injection of $\mathrm{L}-\left(\mathrm{G}-{ }^{3} \mathrm{H}\right)$ tryptophan. The peak of synthesis of acrosomal constituents may be thus revealed in ejaculated spermatozoa using precursors of different specificity.
\end{abstract}

\section{Introduction.}

The labelling of spermatozoon DNA or nucleoprotein during spermatogenesis has been shown to be an effective tool in the study of the fertilization process (see Keneklis, 1976). As reviewed recently, the significance of the acrosomal reaction and the role of acrosomal enzymes in fertilization are still controversial (Bedford and Cross, 1978). Thus, labelling the acrosomal components might offer new possibilities for further research in this area. The labelling of mouse spermatozoon acrosomes by iritiated fucose has been already reported (Kopečný, 1976). Further biochemical work (Sedláková, Kope ný, Čechová, Pivko and Staněk, in progress) seems to confirm the hypothesis that a considerable part of the tritium activity from fucose- ${ }^{3} \mathrm{H}$ labelling will be situated in the proteolytically active glycoproteins, isolated from the rabbit acrosomes. As a cytological counterpart, this paper reports the dynamics of fucose- ${ }^{3} \mathrm{H}$ labelling of the rabbit acrosome using autoradiography. As a parallel to fertilization, we tested the fate of the labelled material in a model situation where the acrosomal membranes and enzymes are progressively lost (Srivastava et al., 1974 ; Williams ef al., 1975). It was shown in addition to this, as the synthesis of acrosomal components is strictly localized during spermiogenesis that the acrosomes could be labelled with precursors of different biochemical specificity. 


\section{Material and methods.}

\section{Spermatozoon labelling}

I. Tritiated fucose-labelled rabbit spermatozoa. - Two male rabbits, $A$ and $B$, were injected intratesticularly with $500 \mu \mathrm{Ci}$ and $250 \mu \mathrm{Ci}$, respectively, of $\mathrm{L}-\left(1-{ }^{3} \mathrm{H}\right)$ fucose (Amersham, specific activity $1.4 \mathrm{Ci} / \mathrm{mmol}$, radioactive concentration : $1 \mathrm{mCi} / \mathrm{ml}$, sterile aqueous solution) per testis. Starting with the day of the injection (day 0 ) and during 1 month after injection, semen was collected twice weekly by ejaculation in an artificial vagina. Smears from all ejaculates were prepared. The progressive loss of acrosomal membranes and enzymes was obtained with the procedures described by Hartree and Srivastava (1965), Srivastava ef al. (1974) and Williams et al. (1975). Sperm samples were processed as follows:

1) control smears were prepared as soon as possible using isotonic saline for dilution ;

2) 1 volume of the sperm sample was washed 3 times for $15 \mathrm{~min}$. by centrifugation at $1400 \mathrm{~g}$ with 4 volumes of $0.05 \mathrm{M}$ Tris- $\mathrm{HCl}$ at about $2{ }^{\circ} \mathrm{C}, \mathrm{pH} \mathrm{7.4,} \mathrm{for} 15 \mathrm{~min}$.; the smears of spermatozoa were prepared during the third washing ;

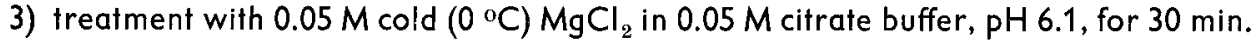
was followed by a short, gentle homogenization in a glass homogenizer stirred by hand ; the treated spermatozoa were smeared ;

4) spermatozoa were resuspended and treated with $0.01 \mathrm{M}$ cetyltrimethylammonium bromide (CTAB) (Hartree and Srivastava, 1965) for $60 \mathrm{~min}$. at $39^{\circ} \mathrm{C}$ and the smears were then prepared. The efficiency of these treatments on acrosome removal was tested with an anoptral negative-phase-contrast microscope.

II. Tritiated tryptophan-labelled mouse spermatozoa. - Three 3-month old male mice $\left(\mathrm{F}_{10} \mathrm{C} 57 \times \mathrm{A}\right)$ were each injected intraperitoneally with $250 \mu \mathrm{Ci}$ of $\mathrm{L}-\left(\mathrm{G}-{ }^{3} \mathrm{H}\right)$ tryptophan (Amersham, specific activity $3.8 \mathrm{Ci} / \mathrm{mmol}$ ). The semen was collected twice weekly by mating until post-injection (p. i.) day 29 , when they were slaughtered and the sperm samples collected from the cauda epididymidis and the ductus deferens.

\section{Autoradiography}

Sperm smears were fixed in formol, phosphate buffered to $\mathrm{pH} 7.1 .0 .5 \mathrm{p} .100$ of cetylpyridinium bromide was added for the fixation of the ${ }^{3} \mathrm{H}$-fucose-labelled material. All slides were washed in running tap water, rinsed with distilled water and with 70 p. 100 alcohol, and then air-dried. ${ }^{3 H}$-tryptophan-labelled sperm smears were extracted with cold 5 p. 100 TCA. The slides were coated with llford $K 5$ liquid nuclear emulsion and exposed for 3 months. The developed autoradiograms were stained with 1 p. 100 toluidine blue at $\mathrm{pH} 4.1$.

\section{Quantitative evaluation of autoradiograms}

Silver grains were counted on 300 heads of fucose-labelled rabbit spermatozoa in the toluidine blue area. Similarly, 100 tryptophan-labelled mouse spermatozoa were checked, but the grain count was noted in the acrosomal region, the postacroso- 
mal region and the mid-piece. The background levels in all autoradiograms were low, since only 0.6 p. 100 of the rabbit sperm heads in the non-labelled smears were associated with 4 grains and none with 5 grains. Spermatozoa with 5 or more grains per sperm head were considered as labelled.

\section{Results.}

Tritiated fucose-labelled rabbit spermatozoa.

A wave of labelled spermatozoa appeared in the ejaculates of both bucks with a sharp peak at p. i. days 24 to 25 (fig. 1). During the peak a maximum of 32 p. 100 of the spermatozoa were labelled with 12.3 grains per sperm in buck $A$ and with 14.0 grains in buck $B$. The influence of the extraction treatments on the morphology of the spermatozoon head and the results of the autoradiographic analysis of the

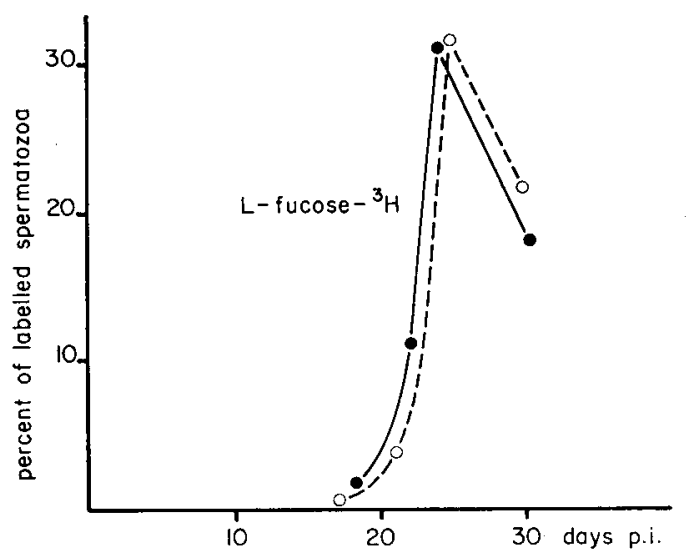

FIG. 1.

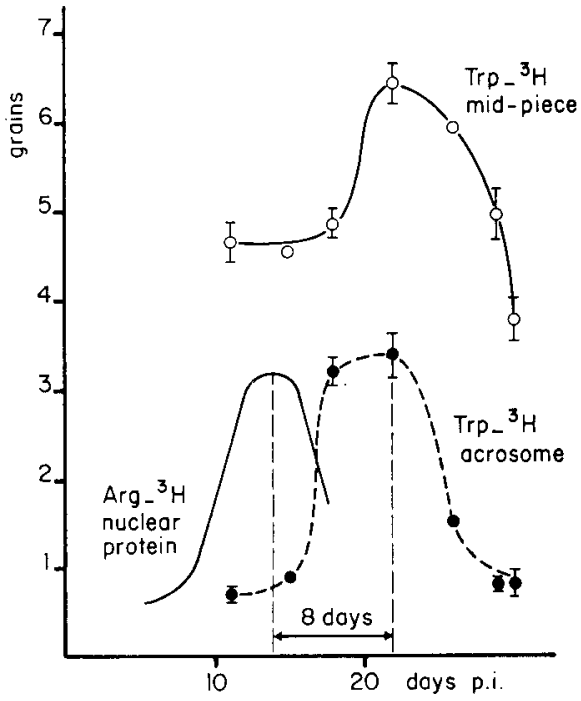

FIG. 3.

FIG. 1. - Excretion pattern of $L-\left(1-{ }^{3} \mathrm{H}\right)$ fucose-labelled rabbit spermatozoa. ( $-\bullet=$ buck $A$, - - - o = buck B). The peak in labelled spermatozoa (spermatozoa labelled by 5 or more grains per sperm head) was reached in the ejaculates collected at 24 and 25 days, respectively, after an intratesticular injection of the labelled precursor.

FIG. 3. - The position of the peak of synthesis of acrosomal proteins in relation to other cytoplasmatic proteins and to the synthesis of basic nuclear proteins as shown by the excretion patfern of $1-\left(\mathrm{G}-{ }^{3} \mathrm{H}\right)$ tryptophan-labelled mouse spermatozoa. The peak of acrosome labelling (• - - - $\bullet$ ) occurred at 22 days after one intraperitoneal injection. In contrast to acrosome labelling, the last synthesis of nuclear material (basic nuclear protein) is observed in spermatozoa ejaculated already one week earlier (solid line - see Discussion). The material constituting the mid-piece is synthesized during both periods of spermatogenesis, as shown in our ${ }^{3} \mathrm{H}$ tryptophan-labelled material by the labelling pattern in ejaculated spermatozoa mid-piece ( $0-0)$. The data represent means \pm s. e. $m$. from the ejaculates collected from three males; single ejaculates are shown as circles. 
fate of the labelled material during extraction are summarized in table 1 and shown in figure 2.

TABLE 1

Effect of extraction treatments on the acrosome morphology, on the autoradiographic image and on the autoradiographic grain yield of ${ }^{3} \mathrm{H}$-fucose-labelled spermatozoo

\begin{tabular}{|c|c|c|c|c|}
\hline $\begin{array}{l}\text { Treatment } \\
\text { of spermatozoa }\end{array}$ & $\begin{array}{l}\text { Acrosome morphology } \\
\text { (phase contrast) }\end{array}$ & $\begin{array}{c}\text { Autoradiographic } \\
\text { distribution of silver grains } \\
\text { over sperm heads }\end{array}$ & $\begin{array}{l}\text { Relative grain } \\
\text { counts over } \\
\text { stained sperm } \\
\text { chromatin } \\
\text { (sperm head } \\
\text { associated } \\
\text { label)* }\end{array}$ & $\begin{array}{l}\text { Dispersed or } \\
\text { lost labelled } \\
\text { material } \\
\text { (p. 100 } \\
\text { of control) }\end{array}$ \\
\hline 1) Control smears & Compact (fig. 2b) & $\begin{array}{l}\text { Intensive labelling in the } \\
\text { acrosomal region (fig. } 2 a \text { ) }\end{array}$ & 100 & 0 \\
\hline 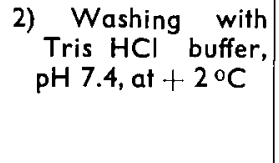 & Swelling & $\begin{array}{l}\text { Dispersion of the grains in } \\
\text { the vicinity of the sperm } \\
\text { head. A part of the grains } \\
\text { remains associated with } \\
\text { sperm heads (fig. 2c) }\end{array}$ & $57 \pm 4.9$ & 43 \\
\hline $\begin{array}{l}\text { 3) Incubation with } \\
\mathrm{MgCl}_{2}, \mathrm{pH} 6.1 \text {, at } \\
0^{\circ} \mathrm{C}+\text { mechani- } \\
\text { cal treatment }\end{array}$ & $\begin{array}{l}\text { Detachment of acrosome } \\
\text { (fig. } 2 d \text { ) }\end{array}$ & $\begin{array}{l}\text { Dispersion of the grains } \\
\text { into increasingly larger } \\
\text { areas. A part of the grains } \\
\text { remains associated with } \\
\text { the sperm heads (figs. } 2 e \text {, } \\
2 f)\end{array}$ & $54 \pm 4.7$ & 46 \\
\hline $\begin{array}{l}\text { 4) Incubation with } \\
\mathrm{CTAB} \text { at } 39^{\circ} \mathrm{C}\end{array}$ & $\begin{array}{l}\text { Loss of all discernible rem- } \\
\text { nants. Heads and tails se- } \\
\text { parated }\end{array}$ & $\begin{array}{l}\text { Decrease of labelling to } \\
\text { back-ground level }\end{array}$ & $18 \pm 1.4$ & 82 \\
\hline
\end{tabular}

* Means of 5 experiments with different ejaculates of both bucks.

\section{Tritiated tryptophan-labelled mouse spermatozoa.}

The peak of acrosomal labelling occurred at p. i. day 22 (fig. 3). No labelling higher than the background values was observed in the postacrosomal area, but the mid-piece also showed a peak of labelling af $p$. i. day 22. The mid-piece was already significantly labelled in the first interval evaluated (p. i. day 10). In contrast, the last intensive incorporation of labelled precursor (arginine) into nuclear proteins was observed in spermatozoa ejaculated at p. i. day 14 (Kopečný and Pavlok, 1975), as shown in figure 3 .

FIG. 2. - Autoradiograms of rabbit spermatozoa ejaculated at 25 days after an intratesticular injection of $\mathrm{L}-\left(1-{ }^{3} \mathrm{H}\right)$ fucose before and after treaiments. a) Strict localisation of the labelling in the area occupied by the intact acrosome in control spermatozoa. b) A negative-phase-contrast microphotograph of the same sample as in (a) immediately before smearing. c), e), f) Autoradiographic visualisation of the effects of washing and of cold $\mathrm{MgCl}_{2}$ incubation on the progressive release of the labelled material. Acrosome swelling and detachment. (d) a phase-contrast control) was followed in the autoradiograms by a continuous dispersal of the silver grains. A part of the grains, however, still remained associated with the sperm heads. Note the linear arrangement of grains in expanded acrosomal material. 


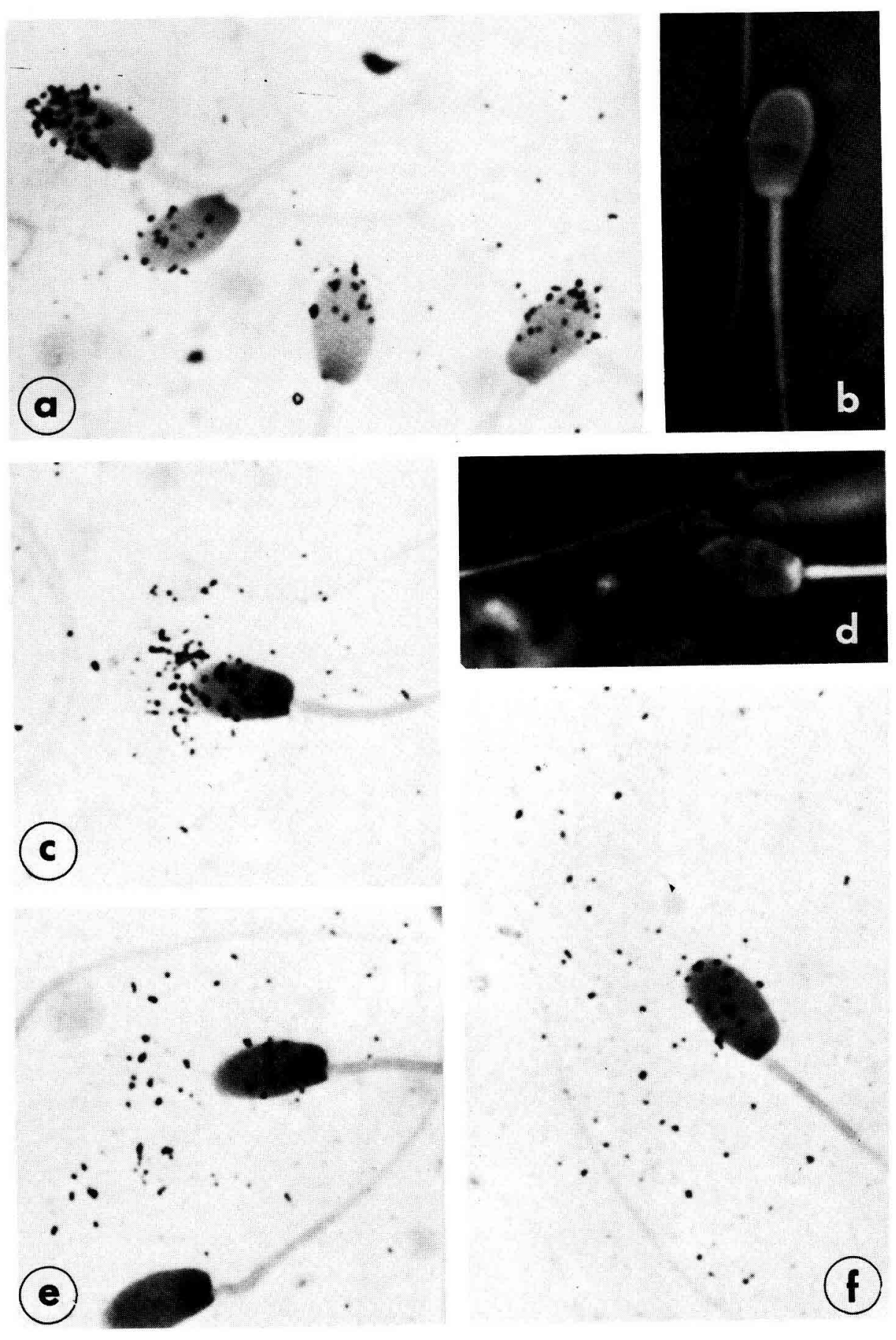




\section{Discussion.}

Incorporation of tritiated fucose in rabbit spermatids was detected in ejaculated spermatozoa 3 weeks after radiochemical injection. The peak of labelled spermatozoon excretion (p. i. days 24 to 25) was such situated between the peak of DNA-labelled spermatozoa, 6 weeks after ${ }^{3} \mathrm{H}$-thymidine injection (Amann et al., 1965), and the peak of spermatozoa labelled in basic nuclear protein 2 weeks after tritiated arginine injection (Kopečný and Fulka, 1975).

The labelling probably represents to a considerable extend the extractable acrosomal glycoproteins. Fucose guarantees a very specific glycoprotein precursor (Bennet et al., 1974 ; Sandoz and Roland, 1976). The acrosome is a specialized lysosome (Allison and Hartree, 1970), and many of the lysosomal enzymes, including acrosomal enzymes, are glycoproteins (Goldstone and Koenig, 1970 ; Fléchon, 1973 ; Schleuning et al., 1976). Furthermore, the extraction procedures used in our experiments showed a progressive loss of labelled material, resembling the extraction pattern of acrosomal enzymes (Williams ef al., 1975). Step 3 in our procedures (cold $\mathrm{MgCl}_{2}$ ) visualized autoradiographically the loss of the more easily soluble acrosomal contents, and step 4 (CTAB) the more tightly bound material and/or the inner acrosomal membrane.

The structural integrity of the dispersed labelled acrosomal materiai in our step 3 as demonstrated by autoradiography was retained longer than the acrosomal ghosts, as seen by phase contrast microscopy. This observation, together with the somewhat linear character of the grain distribution, may be related to the recent concept of proteolytic acrosomal enzyme binding to microlubules (Stambaugh and Smith, 1978).

Acrosomal labelling, as described after fucose administration, may be obtained by other radioactive precursors, which would, in most cases, lack the specificity attributed to fucose labelling. However, they might produce more intensive acrosomal labelling or a selective labelling of other acrosomal moieties. The labelling specificity of acrosomal material can probably be obtained by the already-discussed timing of the excretion pattern of spermatozoa with labelling in the acrosomal system, and it is for this reason that tryptophan- ${ }^{3} \mathrm{H}$ labelling of the mouse acrosome has been studied here. Tryptophan is known to be absent from the basic nuclear proteins and to contribute very little to the acrosin molecule (Schleuning et al., 1976), so that it might be expected that these components in the mature sperm head are not labelled after administration of that precursor. In fact, a peak in acrosome labelling was detected in ejaculated mouse spermatozoa at $p$. i. day 22. A similar peak was found in middle piece labelling, but unlike the acrosomal constituents, those of the mid-piece were synthesized also in the later stages of spermatogenesis concomitantly with the synthetis of the basic nuclear protein (Kopečný and Pavlok, 1975). In contrast to other sperm components, there is probably no further major addition of labelled proteins to acrosomal material after acrosome synthesis. 
Résumé. L'acrosome du spermatozoïde de lapin est fortement marqué après une injection intratesticulaire de $L-\left(1-{ }^{3} \mathrm{H}\right)$ fucose. Le constituant marqué qui est supposé être une glycoprotéine acrosomiale, a été extrait par les techniques connues pour enlever séquentiellement les membranes, puis les enzymes acrosomiales. $\mathrm{La} \mathrm{MgCl}_{2}$ en solution, à froid, permet d'extraire 46 p. 100 du matériel marqué. Un second traitement par le bromure de cétyl-triméthylammonium réduit la radioactivité au niveau du bruit de fond. Chez la souris, le marquage acrosomial est aussi obłenu 22 jours après une injection intrapéritonéale de $\mathrm{L}-\left(\mathrm{G}-{ }^{3} \mathrm{H}\right)$ tryptophane. II est donc possible de marquer les acrosomes par des précurseurs de spécificité différente, qui s'incorporent au moment du pic de synthèse des constituants de l'acrosome.

\section{References}

ALLISON A. C., HARTREE E. F., 1970. Lysosomal enzymes in the acrosome and their possible role in fertilization. J. Reprod. Ferf., 21, 501-516.

AMANN R. P., KOEFOED-JOHNSEN H. H., LEVI H., 1965. Excretion pattern of labelled spermatozoa and the timing of spermatozoa formation and epididymal transit in rabbits injected with thymidine- ${ }^{3} \mathrm{H}$. J. Reprod. Fert., 10, 169-183.

BEDFORD J. M., CROSS N. L., 1978. Normal penetration of rabbit spermatozoa through a trypsinand acrosin-resistant zona pellucida. J. Reprod. Fert., 54, 385-392.

BENNET G., LEBLOND C. P., HADDAD A., 1974. Migration of glycoprotein from the Golgi apparatus to the surface of various cell types as shown by radioautography after labeled fucose injections into rats. J. Cell Biol., 60, 258-284.

FLÉCHON J. E., 1973. Modifications ultrastructurales et cytochimiques des spermatozoïdes de Lapin au cours du transit épididymaire, 115-139. In : Transport, survie et pouvoir fécondant des spermatozoïdes chez les vertébrés. Coll. INSERM, vol, 26, INSERM, Paris.

GOLDSTONE M., KOENIG H., 1970. Lysosomal hydrolases as glycoproteins. Life Sci., Part. II, 9, 1341-1350.

HARTREE E. F., SRIVASTAVA P. N., 1965. Chemical composition of the acrosomes of ram spermatozoa. J. Reprod. Fert., 9, 47-60.

KENEKLIS T. P., 1976. Radioisotope studies on fertilization and preimplantation development. Bibl. Reprod., 27, 1-4, 93-94.

KOPEČNÝ V., 1976. Labelling of acrosomes in mouse spermatozoa by $\mathrm{L}-\left(1-{ }^{3} \mathrm{H}\right)$ fucose. J. Reprod. Fert., 47, $403-405$.

KOPEČNÝ V., FULKA J., 1975. Retaining of nuclear basic protein in rabbit spermatozoa up to the entry to the vitellus. Ann. Biol. anim. Bioch. Biophys., 15, 119-122.

KOPEČNÝ V., PAVLOK A., 1975. Autoradiographic słudy of mouse spermatozoan arginine-rich nuclear protein in fertilization. J. exp. Zool., 191, 95-96.

SANDOZ D., ROLAND J. C., 1976. Radioautographic study of glycoproteins and polyglycans. J. Microsc. Biol. Cell., 27, 207-214.

SCHLEUNING W. D., HELL R., FRITZ H., 1976. Multiple forms of human acrosin : Isolation and properties. Hoppe-Seyler's Z. Physiol. Chemie, 357, 855-865.

SRIVASTAVA P. N., MUNNELL J. F., YANG C. H., FOLEY C. W., 1974. Sequential release of acrosomal membranes and acrosomal enzymes of ram spermatozoa. J. Reprod. Ferf., 36, 363-372.

STAMBAUGH R., SMITH M., 1978. Tubulin and microtubule-like structures in mammalian acrosomes. J. exp. Zool., 203, 135-141.

WILLIAMS W. L., SRIVASTAVA P. N., DUDKIEWICZ A. B., 1975. Membrane and enzymatic events in penetration of the mammalian ovum by sperm. In : TALWAR G. P., Regulation of growth and differentiated function in eucaryote cells. Raven Press, New York. 